\title{
Leydig Cell Tumor of the Testis: A Case with Incidental Diagnosis
}

\author{
Testisin Leydig Hücreli Tümörü: Insidental Tanı Alan Bir Olgu
}

\author{
(D) Ali Erhan Eren1, (1) Mehmet Erhan Aydın2, (1) Evren Aldemir3, (1) Ömer Koraş4, (1) Funda Taşlı5 \\ 1 Gelibolu State Hospital, Clinic of Urology, Çanakkale, Turkiye \\ 2Dr. Yaşar Eryılmaz Doğubayazıt State Hospital, Clinic of Urology, Ağrı, Turkiye \\ ${ }^{3}$ Egepol Hospital, Clinic of Radiology, İzmir, Turkiye \\ ${ }^{4}$ Kemalpaşa State Hospital, Clinic of Urology, Bursa, Turkiye \\ 5 University of Health Science, Izmir Bozyaka Training and Research Hospital, Department of Pathology, Izmir, Turkiye
}

\begin{abstract}
Leydig cell tumors account for approximately 1-3\% of adult testicular tumors. These tumors are the most common type of gonadal stromal tumors and most commonly seen in the third to sixth decades of life, and about 10\% of them are malignant. This case is about an incidentally diagnosed Leydig cell testis tumor in a patient who was investigated for primary infertility. A 28-year-old male patient presented with primary infertility and scrotal ultrasonography examination revealed a heterogeneous hypoechoic mass in the left testicle. He underwent left radical orchiectomy and pathological diagnosis was testicular Leydig cell tumor. There was no distant metastasis and the patient is being followed for metastasis.
\end{abstract}

Keywords: Infertility, Leydig cell tumor, Testicular neoplasms, Inguinal orchiectomy

\section{Öz}

Leydig hücreli tümörler, yetişkin testis tümörlerinin yaklaşık \%1-3'ünü oluşturmaktadır. Bu tümörler gonadal stromal tümörlerin en sık rastlanan türü olup, erkeklerde en yaygın 3 ile 6. dekatlarda görülürler. Leydig hücre tümörlerinin yaklaşık \%10'u maligndir. Bu yazıda primer infertilite nedeniyle araştırılan bir hastada insidental tanı konan bir Leydig hücreli testis tümörü olgusu sunmaktayız. Yirmi sekiz yaşında evli bir erkek hasta primer infertilite şikayeti ile kliniğimize başvurdu ve skrotal ultrasonografi incelemesinde sol testiste heterojen ve hipoekoik bir kitlesi olduğu görüldü. Hastaya sol radikal orşiektomi uygulandı ve patoloji sonucu testis Leydig hücreli tümörü olarak raporlandı. Toraks ve batın bilgisayarlı tomografisinde uzak metastaz saptanmadı ve hasta takibe alındı.

Anahtar Kelimeler: İnfertilite, Leydig hücreli tümör, Testiküler neoplaziler, İnguinal orşiektomi

\section{Introduction}

Leydig cell tumors account for 1-3\% of all adult testicular tumors. These tumors are the most common type of gonadal stromal tumors and most commonly seen in the third to sixth decades (1). New developments in ultrasound imaging have increased the number of Leydig cell tumors discovered (2).

In this report, we present a case of Leydig cell testis tumor incidentally diagnosed during primary infertility investigation.

\section{Case Presentation}

A 28-year-old married male patient presented to our clinic with the complaint of primary infertility. The patient had no additional diseases, such as undescended testes, and history of surgery or trauma. Physical examination was unremarkable. On scrotal examination, the left testis was $7 \times 5 \times 4 \mathrm{~cm}$ in size with a mass measuring approximately $15 \times 20 \mathrm{~mm}$ in the middle part of the left testicle, and the right testis was normal. No other

Correspondence: Mehmet Erhan Aydın MD, Dr. Yaşar Eryılmaz Doğubayazıt State Hospital, Clinic of Urology, Ağrı, Turkiye E-mail: merhanaydin@gmail.com ORCID-ID: orcid.org/0000-0002-3567-9987

Received: 11.02.2019 Accepted: 06.03.2019

Cite this article as: Eren AE, Aydın ME, Aldemir E, Koraş Ö, Taşlı F. Leydig Cell Tumor of the Testis: A Case with Incidental Diagnosis. J Urol Surg 2019;6(3):252-254.

${ }^{\circ}$ Copyright 2019 by the Association of Urological Surgery / Journal of Urological Surgery published by Galenos Publishing House. 
signs, including gynecomastia and enlarged or superficial lymph nodes, were observed.

$\mathrm{FSH}, \mathrm{LH}$, testosterone, prolactin, cortisol, progesterone, and estrogen levels and testicular tumor markers (alpha-feto protein, beta-human chorionic gonadotropin and lactate dehydrogenase) were normal and no abnormality was detected in the spermiogram (Table 1). Scrotal ultrasonography revealed that the left testicle was measured $7 \times 4 \times 3 \mathrm{~cm}$ with a heterogeneous hypoechoic mass of $14 \times 22 \mathrm{~mm}$ in size in the middle part of the left testicle.

He underwent left radical orchiectomy after sperm cryopreservation was performed. The patient was discharged on the postoperative $2^{\text {nd }}$ day. Pathological investigation revealed a testicular Leydig cell tumor measuring $15 \mathrm{~mm}$ in diameter, diffuse positive for inhibin and calretinin while surgical margins were negative and no tumor necrosis, nuclear atypia or vascular

Table 1. The patient's tumor markers, hormonal evaluation and semen parameters

\begin{tabular}{lll}
\hline & Preoperative & Normal range \\
\hline Hormon/tumor marker & & \\
FSH $(\mathrm{mlU} / \mathrm{mL})$ & 6.69 & $1.27-19.26$ \\
$\mathrm{LH}(\mathrm{mlU} / \mathrm{mL})$ & 3.52 & $1.24-8.62$ \\
Testesterone $(\mathrm{ng} / \mathrm{mL})$ & 2.05 & $1.75-7.81$ \\
Prolactin $(\mathrm{ng} / \mathrm{mL})$ & 5.14 & $2.64-13.13$ \\
Progesterone $(\mathrm{ng} / \mathrm{mL})$ & 0.68 & $0.14-2.06$ \\
Ostrogen $(\mathrm{pg} / \mathrm{mL})$ & 17.1 & $15-31.5$ \\
AFP $(\mathrm{ng} / \mathrm{mL})$ & 2.69 & $0-9$ \\
$\beta-\mathrm{hCG}(\mathrm{mlU} / \mathrm{mL})$ & 0.12 & $0.5-2.67$ \\
$\mathrm{LDH}(\mathrm{U} / \mathrm{l})$ & 155 & $0-248$ \\
\hline
\end{tabular}

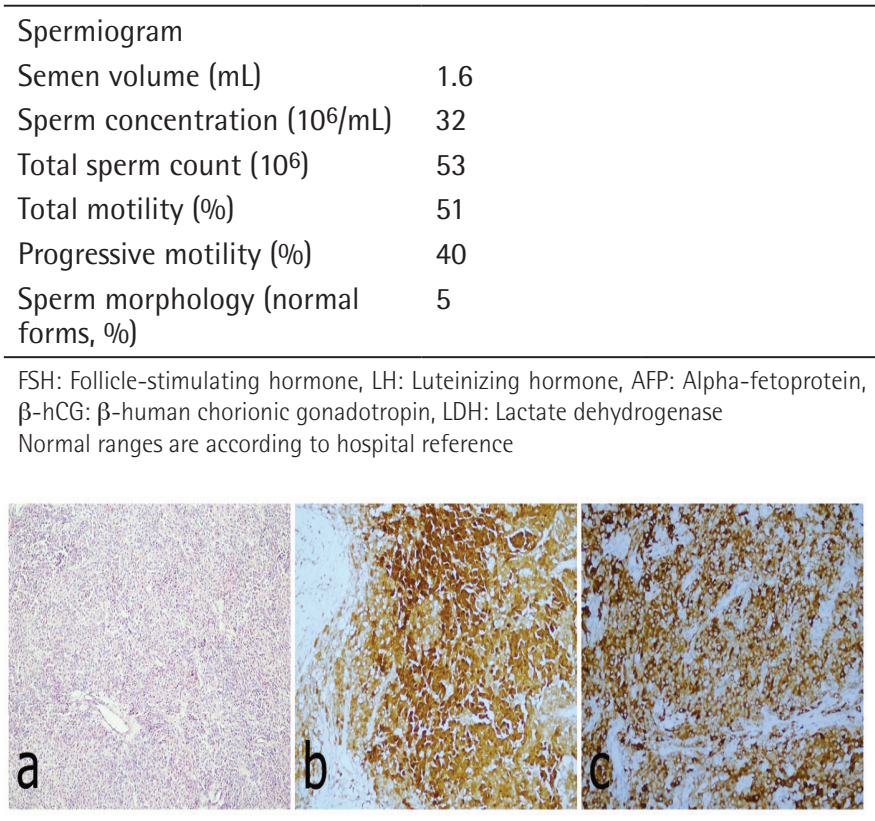

Figure 1. a) Sharp-limited, broad and eosinophilic cytoplasmic tumor cells with solid growth pattern (HE; x100); b) Diffuse calretinin (+) in tumor cells (IHC, Calretinin; x200), c) Diffuse inhibin (+) in tumor cells (IHC, Inhibin; x200) invasion was detected (Figure 1). There was no distant metastasis on thoracic and abdominal contrast-enhanced computed tomography (CT). Subsequently, the patient was referred to the in vitro fertilization center for assisted reproductive techniques.

The patient is still followed regularly at 6-month intervals with thoracic and abdominal contrast-enhanced CT. No distant metastases were seen during the follow-up period. Written informed consent was obtained from the patient.

\section{Discussion}

Leydig cell tumors are relatively rare testicular tumors accounting for $1-3 \%$ of all testicular tumors in adults (1). They are usually diagnosed incidentally as a palpable mass during manual testicular exam or during ultrasonography.

These tumors usually produce hormones. Suardi et al. (3) reported that $80 \%$ of 37 patients with Leydig cell tumor had low testosterone and high estrogen, estradiol, LH and FSH levels while no patient showed increased testicular markers. In our case, testicular tumor markers were negative and LH, FSH, testosterone and estrogen levels were normal (Table 1).

It is estimated that about 30\% of patients with Leydig cell tumors have endocrine symptoms due to abnormal hormone levels (4). Scrotal ultrasonography is the primary imaging method used in the diagnosis, however, investigation of tumor markers, hormones (testosterone, LH, FSH, estrogen, estradiol, progesterone and cortisol) and CT examination of chest and abdomen for distant metastasis should be performed. As in our patient, cases of Leydig cell tumors incidentally diagnosed during infertility investigation have been reported in the literature $(5,6)$.

Malignant transformation of Leydig cell tumors occurs in approximately $10 \%$ of patients. Orchiectomy is the standard treatment. Histopathological and clinical findings of malignant Leydig cell tumors include increased mitotic activity, vascular invasion, large size $(>5 \mathrm{~cm})$, necrosis, cytological atypia, extension beyond the testicular parenchyma, increased MIB1 expression, infiltrative margins and DNA aneuploidy (7). However, the strongest indicator of malignancy is the presence of metastases (8). Malignant tumors occur exclusively in adults and are unaccompanied by endocrine changes $(1,9)$. In our case, the tumors size was $15 \mathrm{~mm}$, the patient was young, there were no vascular invasion, cytological atypia or necrosis and surgical margins were negative and no distant metastasis was found. Thus, this case should not be considered malignant.

In all high-risk patients, physical examination, scrotal and abdominal ultrasonography, evaluation of hormones and CT of the chest and abdomen are recommended every 3-6 months for follow-up (3). 
The rate of metastatic tumors among all reported cases is less than $10 \%$. In three older series, 18 metastatic tumors were found in 83 cases $(21.7 \%)(1,2,10)$, while 5 recently published studies reported only 2 metastatic tumors in 156 cases (1.3\%) $(3,11,12,13,14)$. The most common sites of metastasis are the regional lymph nodes, followed by the liver, lungs, and bones (1). The metastases respond poorly to radiation or chemotherapy and overall survival is poor (15). There is no recommended option for the treatment of metastatic Leydig cell tumors yet. In this case, the patient was followed with every 3-6 month controls and no distant metastasis was seen in radiological exams.

In conclusion, Leydig cell tumors are rare tumors developing from gonadal stroma. They are usually diagnosed incidentally. These tumors are important for their endocrine effects because they often produce hormones. However, normal hormone profile does not exclude Leydig cell tumor. Radical orchiectomy should be performed for the treatment and the patient should be closely monitored for metastasis.

\section{Ethics}

Informed Consent: Written informed consent was obtained from the patient.

Peer-review: Externally peer-reviewed.

\section{Authorship Contributions}

Concept: M.E.A., Design: M.E.A., Ö.K., Data Collection and/or Processing: A.E.E., E.A., Analysis and/or Interpretation: A.E.E., Literature Research: E.A., Ö.K., Writing: M.E.A., F.T.

Conflict of Interest: No conflict of interest was declared by the authors.

Financial Disclosure: The authors declared that this study received no financial support.

\section{References}

1. Kim I, Young RH, Scully RE. Leydig cell tumors of the testis. A clinicopathological analysis of 40 cases and review of the literature. Am J Surg Pathol 1985;9:177-192.

2. Maizlin ZV, Belenky A, Kunichezky M, Sandbank J, Strauss S. Leydig cell tumors of the testis: gray scale and color Doppler sonographic appearance. J Ultrasound Med 2004;23:959-964.
3. Suardi N, Strada E, Colombo R, Freschi M, Salonia A, Lania C, Cestari A, Carmignani L, Guazzoni G, Rigatti $P$, Montorsi F. Leydig cell tumour of the testis: presentation, therapy, long-term follow-up and the role of organsparing surgery in a single-institution experience. BJU Int 2009;103:197200.

4. Woodward PJ, Sohaey R, O'Donoghue MJ, Green DE. From the archives of the AFIP: tumors and tumorlike lesions of the testis: radiologic-pathologic correlation. Radiographics 2002;22:189-216.

5. Mostafid H, Nawrocki J, Fletcher MS, Vaughan NJ, Melcher DH. Leydig cell tumour of the testis: a rare cause of male infertility. Br J Urol 1998;81:651.

6. Tsitouridis I, Maskalidis C, Panagiotidou D, Kariki EP. Eleven patients with testicular leydig cell tumors: clinical, imaging, and pathologic correlation. J Ultrasound Med 2014;33:1855-1864.

7. Cheville JC, Sebo TJ, Lager DJ, Bostwick DG, Farrow GM. Leydig cell tumor of the testis: a clinicopathologic, DNA content, and MIB-1 comparison of nonmetastasizing and metastasizing tumors. Am J Surg Pathol 1998;22:1361-1367.

8. Odabas O, Dilek FH, Avanoglu H, Atilla MK, Yılmaz Y, Aydın S. Leydig cell tumor of the testis. East J Med 1998;3:78-79.

9. Muheilan MM, Shomaf M, Tarawneh E, Murshidi MM, Al-Sayyed MR, Murshidi MM. Leydig cell tumor in grey zone: A case report. Int J Surg Case Rep 2017;35:12-16.

10. Matveev BP, Gurariĭ LL. [Leydig-cell tumors of the testis]. Urol Nefrol (Mosk) 1997:4:34-36

11. Bnerji JS, Odem-Davis K, Wolff EM, Nichols CR, Porter CR. Patterns of Care and Survival Outcomes for Malignant Sex Cord Stromal Testicular Cancer: Results from the National Cancer Data Base. J Urol 2016;196:1117-1122.

12. Bozzini G, Picozzi S, Gadda F, Colombo R, Decobelli O, Palou J, Colpi G, Carmignani L. Long-term follow-up using testicle-sparing surgery for Leydig cell tumor. Clin Genitourin Cancer 2013;11:321-324.

13. Di Tonno F, Tavolini IM, Belmonte $P$, Bertoldin $R$, Cossaro $E$, Curti $P$, D'Incà G, Fandella A, Guaitoli P, Guazzieri S, Mazzariol C; North-Eastern UroOncological Group, Italy. Lessons from 52 patients with leydig cell tumor of the testis: the GUONE (North-Eastern Uro-Oncological Group, Italy) experience. Urol Int 2009;82:152-157.

14. Leonhartsberger N, Ramoner R, Aigner F, Stoehr B, Pichler R, Zangerl F, Fritzer A, Steiner $\mathrm{H}$. Increased incidence of Leydig cell tumours of the testis in the era of improved imaging techniques. BJU Int 2011;108:1603-1607.

15. Mosharafa AA, Foster RS, Bihrle R, Koch MO, Ulbright TM, Einhorn $L H_{\text {, }}$ Donohue JP. Does retroperitoneal lymph node dissection have a curative role for patients with sex cord-stromal testicular tumors? Cancer 2003;98:753757. 